\title{
Kitaplara İlişkin Biçimsel Özelliklerin Okuyucu Tutumları Üzerine Etkisi
}

Effect of Formal Factors about Books on Readers' Attitudes

\section{Mehpare TOKAY ARGAN", Metin ARGAN ${ }^{* *}$ ve Mesut KURULGAN ${ }^{\star *}$}

Öz

Bu çalışmanın amacı, kitap seçimindeki biçimsel faktörleri ve bu biçimsel faktörlerin tutumlar üzerindeki etkilerini ortaya koymaktır. Araştırmada kullanılan anket Anadolu Üniversitesinde öğrenim gören 353 öğrenci üzerinde uygulanmıştır. Çalışma sonucunda, kitap okumada etkili olan beş biçimsel faktör ve kitap okumayı etkileyen dört tutum faktörü ortaya çıkmıştır. Kitap okumada etkili olan biçimsel faktörler; cilt ve kâğıt türü, boyut ve yazım özelliği, sayfalardaki resim ve şekiller, kapağın şekli ve rengi ileiçindekiler ve kaynakçadır. Bunun yanı sıra, biçimsel özelliklerle ilgili dört tutum faktörü belirlenmiştir. Bunlar: Dikkat ve izlenim, isteklilik, okuma zevki ve kolaylaştırıcılıktır. Sonuçlar, biçimsel özelliklere ilişkin faktörlerin tutumlar ile ilişkili olduğunu ortaya koymaktadır. Bu araştırmanın sonuçları, yayınevlerinin ve kitap tasarımcılarının kitap üretimini nasıl değerlendirmeleri gerektiği ve okuyucuların okuma işlevini nelerin etkilediği konusunda önemli çıkarımlar sunmaktadır.

Anahtar sözcükler: Okuyucu, Kitap tüketicisi, Kitap tercihi, Kitap

`Yrd. Doç. Dr.; Bilecik Üniversitesi, Bozüyük MYO. Bozüyük / BiLECiK (mtargan@anadolu.edu.tr).

"Doç. Dr.; Anadolu Üniversitesi Beden Eğitimi ve Spor Yüksekokulu, İki Eylül Kampusu ESKiŞEHIR (margan@anadolu.edu.tr).

Yrd. Doç. Dr.; Anadolu Üniversitesi Porsuk MYO. 26140 ESKIŞEHIR

(mkurulgan@anadolu.edu.tr). 
tasarımı, Biçimsel faktörler.

\begin{abstract}
The purpose of this study is to determine the factors in a new book choice situation and their effects on attitudes about formal features. In the study, a questionnaire was applied on 353 university students at Anadolu University. The results of this study indicated that five factors were about formal features: The kind of cover and paper, characteristics of dimension and writing style, drawings and pictures in pages, shape and color of cover,table of contents and references. Besides, four factors of attitudes about structural features were determined. These are attention and impression, willingness, reading enjoyment, and facilitation. The results showed that factors of formal features are related with attitudes. The results of the research have significant implications as to how publishers interpret production of new book.
\end{abstract}

Keywords: Reader, Book consumer, Book choice, Book design, Formal factors.

\title{
Giriş
}

Günlük yaşantıda kitap özel bir ürün şekli olup, kitap okuma ise tüketim faaliyetlerinin özel bir türüdür. Bu bakımdan kitap, diğer ürünlerle karşılaştırıldığında özel bir alanda değerlendirilebilir. İnsanlar kitabı eğlenmek, boş zamanlarını değerlendirmek, bilgi edinmek gibi farklı amaçları yerine getirmek için okumaktadır. Kitap okumaya ilişkin yapılan bir araştırmada, okuma olgusu deneyim yaşamayı da ifade etmektedir (Leemans, 1988, ss. 123-124). Bu deneyim; faydacı (bilgiyi artırma), haz alıcı veya hedonik (kitaptaki bir kişiyi veya olguyu sevme) ve sembolik (kendini entelektüel hissetme) güdüleri kapsar.

Okuyucular farklı amaçlarla kitap okumakta ve bu süreçte bazı ortak noktalara dikkat etmektedir. Günümüzde ürün olarak kitapların okuyucularına en iyi biçimde hazırlanmasında biçimsel ve tasarımsal üstünlüklerden yararlanıldığı görülür. Ürünün tasarımı okuyucu algılamalarını etkilemekte, nihayetinde kitaba karşı olumlu tutumlar ortaya çıkabilmekte ve ürün olarak kitap, satın alma niyetine dönüşebilmektedir. Bundan dolayı ürün geliştirme konusunda yapılan araştırmaların büyük çoğunluğu 
tüketici veya okuyucu perspektifinden değerlendirilmektedir. Kitap tüketicilerine en uygun ürünlerin sunumu için, okuyucu bakış açısını ortaya koyan modern yaklaşımlar büyük önem taşır. Bu bakımdan, kitap okumayı etkileyen unsurların belirlenmesi yayıncılar için de çok önemli bir konudur (Kurulgan ve Argan, 2006, s. 231).

Her yıl yeni isimli binlerce kitap basılıp okuyucuların ilgi ve dikkatine sunulmaktadır. Örneğin, Türkiye'de Kültür ve Turizm Bakanlığı verilerine göre 2006 yılında yaklaşık 35 bin kitap basımı yapılmıştır. Avrupa ülkelerindeki ise bu sayı ortalama 50 bin civarındadır (2006 yılında, 2007). Basılan kitap sayısının çokluğu, tüketicinin kitaba dikkatini çekmeye yönelik yoğun bir rekabeti de beraberinde getirmektedir (D'Astous, Colbert ve Mbarek, 2006, s. 134).

Çalışmamızda, biçimsel özelliklerin okuyucuların kitap okumaya yönelik tutum faktörleri üzerindeki etkilerini ortaya çıkarmak amaçlanmıştır. Bu bağlamda, okuyucuların kitap tercihlerinde etkili olan biçimsel veya dışsal olarak nitelendirilebilecek unsurları ortaya koyan faktörleri belirleyen çalışma, kitap üretiminin taraflarına da yeni açılımlar sağlayabilecektir.

\section{Kuramsal Çerçeve ve Araştırma Hipotezleri}

Kitaplar günlük yaşantıda önemli bir yer tutmaktadır. Kitap okuma kişinin okuma alışkanlığına, okuma kültürüne ve demografik özelliklerine göre farklılık göstermektedir. Kitaplar da, insanların ihtiyaçlarını giderecek şekilde tasarlanan ürünler kapsamında değerlendirilmektedir. Bu açıdan ürün özellikleri, satın alma karar sürecinde önemli bir etkiye sahiptir (Richins ve Bloch, 1991, ss. 145-146; Babin, Babin ve Boles, 1999, ss. 91-92).

Kitapların satın alınma veya tercih edilme aşamasında kitabın biçimsel özellikleri genel olarak değerlendirildiğinde; kağıt türü, sayfa düzeni, yazıların puntosu, içindekiler bölümü, şekil, resim ve kapak yer almaktadır (Sever, 2007; Tortop ve Barışcan, 2007; Akınoğlu, Şahin ve Gürdal, 2008). Bunların her biri kitabın biçimsel özelliğini oluşturmakla birlikte, satın alma aşamasında veya kitabın tercih edilmesinde önemli görevler üstlenmektedir. Bu bakımdan, yeni bir kitap üzerinde insanların ilgisini toplamak, 
yayıncılar için de önemli bir konudur. İlgi toplama konusunda tüketicilerin görsel bazı ip uçlarına intiyacı vardır.

Kitapların ürün olarak okuyucuya sunulmasında biçimsel özelliklerinin çekiciliği, yeni bir kitabın okuyucular tarafından değerlendirilmesinde olumlu katkı sağlar. Biçimsel özellikler kapsamında görsel ipucu olarak ürünün ambalajı, tüketicilerin ilgisini çekmede önemli bir rol oynamaktadır. Aynı anlayışla bir kitabın kapağı da ambalajın yapmış olduğu işlevi yerine getirerek, okuyucunun dikkatini çekmektedir. Pazarlamada bir ürün ambalajının asgari bazı işlevleri bulunmaktadır (İslamoğlu, 2006, s. 305). Bunlar koruyuculuk, kolaylık, bilgi verme ve tutundurma işlevleridir. Benzer şekilde, kitabın kapak içeriği koruyuculuğunun yanı sıra, kitabın kalite ve içeriği ile ilgili doğrudan (örneğin; başlık, şekil ve resim) ve dolaylı (örneğin; renk ve kapak malzemesi) bilgiler verir. Stokmans ve Hendrickx (1994) de benzer şekilde kitap kapağının tüketicinin dikkatini çekmede önemli bir unsur olduğunu işaret etmektedir. Piters ve Stokmans (1997, s. 41) ise; kitap kapağı veya ambalajının satın alma kararında, tüketicilere yol gösterdiğini öne sürmektedir. Özetle, kitaplara ait her türlü biçimsel özellik; kitap konusunda okuyucuda yeni izlenimler oluşturarak, satın alma niyeti üzerinde olumlu etki yapar (Kurulgan ve Argan, 2006, s. 232). Satın alma niyeti (purchase intent) tüketicinin bir ürünü satın alma olasılığının ölçümü olarak değerlendirilmektedir (Schiffman ve Kanuk, 2000). Bu yaklaşım çerçevesinde kitaplar değerlendirilirken, biçimsel özellikler; bazı durumlarda ana öğe, bazı durumlarda ise destekleyici öğe olarak işlev görmektedir. Satın alma veya tercih etme kararını hızlandırıcı bir etkiye sahip olan ambalaj ve ürünün biçimsel özellikleri, kitap konusunda da benzer bir işleve sahip olduğu söylenebilir.

Futas'ın (1977) 160 okul kütüphanesi üzerinde yaptığı araştırmada, kütüphanelerin kitap satın alma işlemlerinde en önemli faktörün kitap incelemeleri olduğu belirtilmektedir. Blake (1989)'ın çalışmasında da benzer sonuçlara ulaşılmıştır. Wang ve Soergel (1998) tarafından yapılan bir başka çalışmada; araştırmacının belge seçiminde, belgeye ilişkin başlık, yazar, öz, tarih ve tür gibi bibliyografik bilgilerin, alan bilgisi, yenilik, kalite gibi unsurların ve kişisel özelliklerin etkili olduğu saptanmıştır. Uçak ve 
Güzeldere'nin (2006) gerçekleştirdikleri bir başka araştırma, Wang ve Soergel'in çalışmalarını destekler niteliktedir. Bu çalışmada kullanıcının bilişsel yapısı, ilgililik, bilgi arama davranışı ve bu kavramlar arasındaki ilişki incelenerek daha iyi bilgi erişim sistemleri geliştirme yönünde önerilerde bulunulmaktadır. Yapılan bu araştırmalar, kitap satın alma veya tercih etme kararında, kitap incelemelerinin ve kişisel özelliklerin önemli olduğunu göstermektedir (Lin, Luarn ve Huang, 2005, s. 461).

Kitapların biçimsel özellikleri ile birlikte tüketicilerin bu özelliklere yönelik tutumları da farklılık gösterebilmektedir. Bu tutumlar kitap okuma sürecinde karar almayı etkileyebilmektedir. Tutum, genel olarak bireyin kendine veya çevresindeki herhangi bir konu, obje/olaya karşı; deneyim, motivasyon ve bilgilere dayanarak örgütlediği bilişsel, duygusal ve davranışsal tepki eğilimidir. Bireylerin tutumları, deneyimlerinin ve edindiği bilgilerin örgütlenmesiyle oluşur (Odabaşı ve Barış, 2002, s.160). Tüketicilerin biçimsel özelliklere yönelik tutumları, kitap tercihi ve okuma işlevi üzerinde önemli bir etkiye sahiptir. Örneğin tutumların oluşmasında kitabın tasarımı, tüketicilerin dikkatini çekmede rol oynamaktadır (D'Astous, Colbert ve Mbarek, 2006, s. 134). Kitap tasarımı tüketici algılamalarını etkilemekte, kitaba karşı olumlu tutumlar ortaya çıkarabilmekte ve sonuçta satın alma niyetine dönüşebilmektedir. Ayrıca aranılan konuyu rahatlıkla bulabilme ya da kısaltmalarla ilgili ön bilgilere ulaşabilme, kitapların biçimsel özelliklerine yönelik tutumları etkilemektedir. Noyes ve Garland (2005, s. 235)'a göre, bir kitabın estetik kalitesi ve biçimsel özellikleri yayıncılar tarafından göz önünde bulundurulması gereken önemli öğelerdendir.

Tüketicilerin veya okuyucuların kitap okuma tercihinde nelere dikkat ettikleri konusunda yapılan çalışmalar oldukça sınırıdır. Bu çalışmalarda kitap tercih etme ve okuma olgusunun oldukça karmaşık bir süreç olduğu belirtilmektedir. Çalışmaların büyük çoğunluğunda; özellikle yazarın ve yayıncının ünü, kitabın kapağı gibi faktörlerin etkili olduğu bulunmuştur. Türkiye'de yapılan bir araştırmanın bulguları da bu faktörleri destekler niteliktedir. Ayyıldız ve arkadaşları tarafından yapılan araştırmada, öğrenci- 
lerin kitap satın alırken veya tercih ederken özellikle yazara ve yayın evine göre karar verdikleri ortaya çıkmıştır (Ayyıldız, Bozkurt ve Canlı, 2006).

Kitapların biçimsel özellikleri kitap okuma üzerinde önemli bir etkiye sahiptir. Örneğin; kitabın puntoları ile şekiller, resimler, ve açıklayıcı bilgiler içermesi ya da okuyucunun kitap içinde bulmak istediği konu veya dizin hakkında ayrıntılı bilgiler vermesi, kitap okumayı ve anlamayı etkileyecek belirgin özelliklerdir. Kitapların biçimsel özellikleri bir kitabın dikkat çekmesini ve tercih edilmesini etkilerken, aynı zamanda okuma esnasında okuyucuya bazı olumlu veya olumsuz deneyimler yaşatabilmektedir. Örneğin, satır aralığının az olması, yazı puntolarının küçük veya çok büyük olması okumayı etkilemektedir. Bu açıdan kitabın biçimsel özellikleri, okuyucunun, okumaya yönelik tutumlarını etkileme gücüne sahiptir.

Bu bağlamda bir kitabın biçimsel özelliklerine ilişkin tutumun, biçimsel özellikler hakkındaki olumlu ve olumsuz tüm düşünce, duygu ve davranışlardan oluştuğunu söylemek mümkündür. Sonuç olarak; biçimsel özelliklere ait tüketici tutumlarının olumlu olması, kitabın tercih edilmesi ve okunması üzerinde etkili olabilmektedir. Çalışmamızda kitap tercihinde önemli olan biçimsel faktörlerin okumaya yönelik tutumlar üzerindeki etkileri ortaya konulmaya çalışılmış ve bu doğrultuda araştırmanın gerekçeleri ve hipotezleri aşağıdaki gibi oluşturulmuştur.

D'Astous, Colbert ve Mbarek (2006)'e göre bir ürün olarak kitabın ambalajı gibi görsel ipuçları tüketicilerin dikkatini çekmede önemli bir role sahiptir. Benzer şekilde Stokes (1985) ürün ambalajının pazarlama fonksiyonlarını yerine getirerek, bilinmeyen bir ürün bağlamında algılanan kalite için belirleyici bir ön bilgi olduğunu ifade etmiştir.

D’Astous, Colbert ve Mbarek (2006) ayrıca, ürün olarak kitabın biçimsel özelliklerinin okuyucu üzerinde ilk izlenim yaratmada olumlu bir etkiye sahip olduğunu belirtmektedir. Bu bakımdan kitapların biçimsel özellikleri; anlama, algılama, dikkat çekme gibi "dikkat ve izlenim" olarak adlandırılabilecek olgu ile ilişkilidir. Yapılan bu araştırma bağlamında, kitap tercihinde biçimsel değerlendirme yapmada ortaya çıkan faktörler, okuma işlevi üzerinde bir etki 
yaratabileceği düşüncesinden hareketle ilk hipotez: "Kitap seçimini etkileyen biçimsel özellikler ile dikkat ve izlenim arasında olumlu bir ilişki bulunmaktadır" şeklindedir.

D'Astous, Colbert ve Mbarek'in, (2006) yaptıkları araştırma, çekici kitap kapaklarının okuyucularının dikkatini ve ilgisini daha fazla çekebileceği yönündeki hipotezi doğrulamıştır. Bu araştırmada da, "dikkat ve ilgi çekenin isteklilik yaratabileceği" görüşünden hareketle, kitap okumayı etkiyen biçimsel özelliklerin isteklilik yaratmada olumlu bir etkiye sahip olabileceği düşüncesi bağlamında, ikinci olarak "kitap seçimini etkileyen biçimsel özellikler ile kitap okuma istekliliği arasında olumlu bir ilişki bulunmakta" olduğu hipotezi öne sürülmüştür.

Kitap seçiminde göz önünde bulundurulan değişkenler, tüketicilerin ürüne olan ilgilenim düzeyine göre değişkenlik gösterir (Leemans, 1988, ss. 123-124). Farklı alanlarda yürütülen çalışmalar objelere ilişkin özelliklerin birbirleriyle uyumlu olması durumunda genellikle daha olumlu değerlendirmeler yapılabildiğini göstermektedir (McDonald, 1991; Meenaghan, 1983). Kitap okumayı etkileyen faktörler olarak biçimsel özelliklerin kitap okumadan alınan zevk üzerinde bir etkiye sahip olabileceği düşüncesinden hareketle "kitap seçimini etkileyen biçimsel özellikler ile okuma zevki arasında olumlu bir ilişki bulunmaktadır" hipotezi ortaya konulmuştur.

Kitapların biçimsel özellikleri, okuyucu üzerinde olumlu bir etkiye sahiptir. Özellikle, okumayı kolaylaştırma bağlamında biçimsel olarak iyi organize edilmiş kitapların okuma olgusunu kolay bir hale getirebileceği düşüncesinden hareket ederek "kitap seçimini etkileyen biçimsel özellikler ile kolaylaştırıcılık özelliği arasında olumlu bir ilişki bulunmaktadır" hipotezi sınanmıştır.

\section{Araştırmanın Amacı}

Kitabın ürün olarak müşteriye sunulması aşamasında satın almayı etkileyen pek çok faktör bulunmaktadır. Kitap konusunda yapılan araştırmalarda, bu faktörler; yazarın ünü, kişinin geçmiş deneyimi, kitabın içeriği, konusu ve türü biçiminde incelenmektedir (Leemans ve Stokmans, 1992, ss. 27-28). Ancak, kitapların okuyucular 
tarafından biçimsel olarak değerlendirildiği ve biçimsel özelliklerin okuma olgusu üzerindeki etkileri konusundaki çalışmalar son derece sınırlıdır (D’Astous, Colbert ve Mbarek, 2006, s. 135).

Kitapların biçimsel özellikleri, okuyucular tarafından kitap okuma işlevi üzerinde belirli etkilere sahiptir. Bu olgudan hareketle gerçekleştirilen bu araştırmada amaç, varolan literatüre katkı sağlayarak bu alandaki akademik çalışmalara yardımcı olmaktır. Aynı zamanda kitapların biçimsel özelliklerinin okuyucuların okuma işlevi üzerindeki etkilerini ortaya koymak için öne sürülen hipotezlerin test edilmesi de amaçlanmaktadır.

$\mathrm{Bu}$ araştırmanın diğer bir amacı, Anadolu Üniversitesi Merkez Kütüphanesi'ni kullanan öğrencilerin arasında okumayı etkileyen kitabın biçimsel özelliklerini ve bunların okuma işlevi üzerindeki etkisini ortaya koymaktır. Bu amaç çerçevesinde araştırmada üç temel aşama söz konusudur:

> Kitap okumayı etkileyen biçimsel faktörlerin belirlenmesi,

> Kitapların biçimsel özelliklerine ilişkin tutumların belirlenmesi,

> Kitapların biçimsel özelliklerinin kitap okumaya yönelik tutumlar üzerindeki etkisinin belirlenmesi.

\section{Yöntem}

Araştırma amaçlarına uygun olarak "betimsel" ve "bağıntısal" araştırma modelleri kullanılmıştır. Betimsel araştırmalar, bir konudaki herhangi bir durumu saptamayı hedefleyen araştırmalardır (Erdoğan, 1998, ss. 60-61). Bağıntısal araştırma modeli ise değişkenler arası ilişkileri ve bu ilişkilerin düzeyini inceler (iftar, 2000). Bu araştırma modellerinde amaç; eldeki problemi, bu problemle ilgili durumları, değişkenleri ve değişkenler arası ilişkileri tanımlamaktır (Kurtuluş, 1998, s. 310). Bu araştırmada öncelikle kitap okumayı etkileyen biçimsel özellikler faktör analizi ile betimlenmiş, daha sonra ise bağımlı değişkenler ile faktörler arasındaki ilişki ve farklılık düzeyi belirlenecektir. Sözü edilen araştırma amaçları ve yapılacak analizler doğrultusunda betimsel ve bağıntısal araştırma modellerinin uygun olduğu şeklinde bir değerlendirme yapmak mümkündür. 


\section{Araştırma ve Anket Tasarımı}

Araştırma için üç bölümlük bir anket formu geliştirilmiştir. Birinci bölüm kitap okumayı etkileyen biçimsel özelliklerin önemini ortaya koyan 13 ifadeden oluşmaktadır. Bu bölümdeki ifadeler beşli Likert Ölçeği ile ("5" çok önemli, "1" hiç önemli değil) okuyucular tarafından değerlendirilmiştir. Anketin ikinci bölümü okuyucunun okumaya yönelik tutumlarını ortaya koymaktadır ve kitapların biçimsel özelliklerine ilişkin 17 tutum ifadesi, beşli Likert ölçeği ile değerlendirilmiştir ("5" kesinlikle katılıyorum, "1" hiç katılmıyorum). Araştırmanın üçüncü ve son bölümü ise, kitap okuyucularının demografik ve kitap okuma alışkanlıklarına ilişkin soruları kapsamaktadır.

\section{Örneklem}

Bu çalışmanın evreni, Eskişehir'de bulunan Anadolu Üniversitesi Merkez Kütüphanesi'nden yararlanan öğrencileri kapsamaktadır. 2005 yılı itibariyle kütüphanenin yıllık ziyaretçi sayısı yaklaşık 529.000'dur. Araştırma verileri, 7 Kasım 2005-30 Aralık 2005 tarihleri arasında toplanmıştır ve bu tarihler arasındaki ziyaretçi sayısı 76.813'tür. Bu ziyaretçi sayısı dikkate alınarak araştırma evreni için kabul edilebilir örnek büyüklüğü 384'tür (Altunışık, Çoşkun, Bayraktaroğlu ve Yıldırım, 2005, s. 127). Araştırmanın yapıldığı dönemdeki ziyaretçi sayısını temsil edecek örneklem yeterliliği için toplam 400 anket dağıtılmış, bunlardan 353 adedi değerlendirmeye alınmıştır. Dört adet anket değerlendirme için eksik veya istatistiksel olarak asgari veri girişine uygun olmadığı için değerlendirmeye alınmamıştır. Dağıtılan anket bazında geri dönüş oranı $\% 88.2$ olarak gerçekleşmiştir.

Araştırmada tesadüfî olmayan örnekleme yöntemlerinden biri olan kolay yoldan örnekleme yöntemi kullanılmıştır. Kolayda örnekleme yönteminde, bir alışveriş merkezinde dolaşan ve caddelerde veya belli bir mekânda bekleyen insanlara anketler uygulanmaktadır (Nakip, 2004, s. 140; Yükselen, 2000, s. 69). Bu doğrultuda anketler, Anadolu Üniversitesi Merkez Kütüphanesi'ni ziyaret eden öğrencilere çalışma amacının belirtilmesinin ardından araştırmaya katılmayı gönüllü olarak kabul edenlere dağıtılmış ve 
kişi yönelimli (self administered) teknik ile elde edilmiştir. Bu teknikte anketörler anket formlarını örneklem grubuna dağıtır, örneklem grubundaki kişiler de soruları tek tek okuyarak cevaplandırır. Kişi yönelimli çalışmalar, eğitim durumu yüksek olan kişiler üzerinde daha çok uygulanmaktadır. Bu araştırmada örneklem grubu üniversite öğrencilerinden oluştuğu için kişi yönelimli yöntem kullanılmıştır. Ankette kullanılan ifadelerin anlaşılırlığını test etmek amacıyla 30 öğrenci üzerinde pilot bir çalışma yapılmış ve ankete ilişkin gerekli düzeltmeler yapılarak son biçimi verilmiştir. Anketi doldurma süresi ortalama olarak 1218 dakikada gerçekleşmiştir.

\section{Bulgular}

\section{Araştırma Katılımcılarına İlişkin Özellikler}

Araştırmaya katılan 353 öğrencinin \%42.8'i (151 kişi) erkek, \%57.2'si (202 kişi) kadındır. Bunlardan \%81.9'u (289 kişi) fakülte öğrencilerinden oluşurken, \%6.5'i enstitü (23 kişi), \%4.9'u yüksekokul (17 kişi), \%4.2'si meslek yüksekokulu (15 kişi) ve \%2.5’i (9 kişi) diğer birimlerdeki öğrencilerdir. Araştırmaya katılan öğrencilerin \%51.4'ü (176 kişi) 251-500 YTL arası, \%32.9'u (113 kişi) 250 YTL veya daha düşük, \%12.8'i (44 kişi) 501-750 YTL arası ve \%2.9'u (10 kişi) ise 751 YTL veya daha fazla aylık ortalama harcama gerçekleştirmektedir.

Ankete katılan öğrencilerin yıllık bazda kitap için ortalama bütçeden ayırdıkları miktar değerlendirildiğinde; 100 YTL veya daha düşük bir miktar ayıranların oranı en yüksek olup \%54.4 (192 kişi), 101-200 YTL arası miktar ayıran öğrencilerin oranı \%21.5 (76 kişi), 201-300 YTL arası para ayıranların oranı \%12.7 (45 kişi), 301 YTL veya daha fazla miktar ayıranların oranı \%5.9 (21 kişi) ve hiç pay ayırmayanların oranı ise \%5.5'tir (19 kişi). 
Tablo 1: Araştırma Katıımcılarına İlişkin Özellikleri N= 353

\begin{tabular}{lcc} 
Özellikler & Sıklık & $\%$ \\
\hline Cinsiyet & & \\
\hline Erkek & 151 & 42.8 \\
Kadın & 202 & 57.2 \\
\hline Akademik Birim & & \\
\hline Enstitü & 23 & 6.5 \\
Fakülte & 289 & 81.9 \\
Yüksekokul & 17 & 4.9 \\
MYO & 15 & 4.2 \\
Diğer & 9 & 2.5 \\
\hline
\end{tabular}

\begin{tabular}{|c|c|c|}
\hline Özellikler & Sıklık & $\%$ \\
\hline \multicolumn{3}{|c|}{ Yararlanılan Kaynaklar } \\
\hline Ders Kitabı & 223 & 63.2 \\
\hline Ders Dışı Kitap & 66 & 18.7 \\
\hline Diğer & 64 & 18.1 \\
\hline \multicolumn{3}{|c|}{ Kütüphaneye Gitme Sıklığı } \\
\hline Yaryylda Birkaç Kez & 24 & 6.8 \\
\hline Ayda Birkaç Kez & 103 & 29.2 \\
\hline HerHafta/DahaSIk & 226 & 64.0 \\
\hline \multicolumn{3}{|c|}{ Ödünç Alınan. Kitap Sayısı } \\
\hline Hiç & 90 & 25.5 \\
\hline $1-5$ & 146 & 41.4 \\
\hline $6-10$ & 39 & 11.0 \\
\hline $11-15$ & 19 & 5.4 \\
\hline $16-20$ & 25 & 7.1 \\
\hline 21 veya > & 34 & 9.6 \\
\hline
\end{tabular}

\begin{tabular}{lcc}
\multicolumn{3}{l}{ Aylık Ort. Harcama Miktarı } \\
\hline 250 YTL veya $<$ & 113 & 32.9 \\
$251-500$ YTL & 176 & 51.4 \\
$501-750$ YTL & 44 & 12.8 \\
751 YTL veya > & 10 & 2.9 \\
\hline Ylllk Kitap Bütçesi & &
\end{tabular}

$\begin{array}{lcc}\text { Hiç ayırmayan } & 19 & 5.5 \\ \text { 100 YTL veya }< & 192 & 54.4 \\ \text { 101-200 YTL } & 76 & 21.5 \\ \text { 201-300 YTL } & 45 & 12.7 \\ \text { 301 YTL veya }> & 21 & 5.9\end{array}$

Araştırmaya katılan öğrencilerin en çok yararlandıkları kaynaklar incelendiğinde \%63.3'ünün (223 kişi) ders kitaplarından, \%18.7'sinin (66 kişi) ders dişı kitaplardan ve \%18.1'inin (64 kişi) ise kitap dışında kalan (gazete, dergi, özgün tez, CD vb.) diğer kaynaklardan yararlandıkları bulunmuştur. 
Araştırma katılımcılarının kütüphaneye gitme sıklığı değerlendirildiğinde; \%64'ünün (226 kişi) bir eğitim-öğretim yarıyılında ortalama her hafta veya daha sık, \%29.2'sinin (103 kişi) ayda ortalama birkaç kez (1-3 kez) ve \%6.8'inin (24 kişi) ise yarıyılda ortalama birkaç kez (1-3 kez) kütüphaneye gittiği anlaşılmıştır.

Araştırmaya katılan kişilerin bir eğitim-öğretim döneminde Anadolu Üniversitesi Merkez Kütüphanesi'nden kitap ödünç alma durumu incelendiğinde; \%41.4'ünün (146 kişi) 1-5 kitap aldığı, \%25.5'inin (90 kişi) hiç ödünç kitap almadığı, \%11'inin (39 kişi) 610 kitap, \%9.6'sının (34 kişi) 21 veya daha fazla sayıda kitap, \%7.1'inin (25 kişi) 16-20 kitap ve \%5.4'ünün (19 kişi) ise 11-15 kitabı ödünç aldığı görülmektedir (Bkz. Tablo 1).

\section{Kitap Okumayı Etkileyen Biçimsel Özelliklere İlişkin Faktörler}

Kitap okuyucularının ürün olarak kitapları biçimsel bakımdan değerlendirmeleri için 13 değişkeni değerlendirmeleri istenmiştir. $\mathrm{Bu}$ değişkenlerin gruplandırılması, sınıflandırılması ve ana faktörlere dönüştürülmesi amacıyla Faktör Analizi (Principal Component Factor) uygulanmıştır. Yapılan analiz sonuçlarına ilişkin bulgular Tablo 2'de verilmiştir.

Kitapların biçimsel özelliklerine ilişkin değişkenlere faktör analizinin uygulanması için "örneklem yeterliliğine bakmak gerekmekte ve yeterliliğe karar vermek için Kaiser-Meyer-Olkin (KMO) testinden yararlanılmaktadır" (Zhang ve diğerleri 2003). Yapılan bu araştırmada KMO 0.679 olup, faktör analizinin uygulanabilmesi için bu oran yeterlidir. Bartlett Test for Sphericity (BTS) $1157.397(p=.000)$ ise bir matris belirleyicisi olarak değişkenlerin varyans hipotezi ve kovaryans matrisinin reddedildiğini ve bir faktör analizi yapmaya uygun olduğunu göstermektedir. Tüm faktörler için öz değer (eigen-value) 1'den büyük olarak atanmıştır. 
Tablo 2: Kitap Tercihinde Etki Eden Biçimsel Faktörler

\begin{tabular}{|c|c|c|c|c|c|c|}
\hline Faktörler & ORT & S.S. & $\begin{array}{l}\text { Faktör } \\
\text { Yükleri }\end{array}$ & $\begin{array}{c}\text { Öz } \\
\text { Değer }\end{array}$ & $\begin{array}{c}\text { Açıklanan } \\
\text { Varyansın } \\
\% \text { 'si }\end{array}$ & $\begin{array}{c}\text { Alpha } \\
\quad \alpha\end{array}$ \\
\hline 1.Faktör: Cilt ve Kâğıt Türü & & & & \multirow{4}{*}{3.48} & \multirow{4}{*}{26.78} & \multirow{4}{*}{.79} \\
\hline Cilt türü (deri, karton, parlak kâğıt vb.) & 3.44 & 1.13 & .76 & & & \\
\hline Kitapta kullanılan kâğıdın kalitesi & 3.79 & 1.01 & .83 & & & \\
\hline Kitapta kullanılan kâğıdın rengi & 3.67 & 1.10 & .84 & & & \\
\hline 2. Faktör: Boyut ve Yazım Özelliği & & & & \multirow{5}{*}{1.77} & \multirow{5}{*}{13.64} & \multirow{5}{*}{.67} \\
\hline Kitaptaki sayfa sayısı & 3.27 & 1.17 & .75 & & & \\
\hline Kitapta kullanılan yazı puntosu & 3.83 & 0.94 & .72 & & & \\
\hline Kitapta kullanılan yazının satır aralığı & 3.47 & 1.07 & .64 & & & \\
\hline Kitabın boyutu veya büyüklüğü & 3.16 & 1.00 & .58 & & & \\
\hline \multicolumn{7}{|l|}{$\begin{array}{l}\text { 3. Faktör: Sayfalardaki Resim ve } \\
\text { Şekiller }\end{array}$} \\
\hline Kitaptaki sayfalarda kullanılan resimler & 3.60 & 1.01 & .85 & \multirow{2}{*}{1.58} & \multirow{2}{*}{12.17} & \multirow[b]{2}{*}{.81} \\
\hline Kitaptaki sayfalarda kullanılan şekiller & 3.59 & 1.03 & .82 & & & \\
\hline 4. Faktör: Kapağın Rengi ve Şekli & & & & \multirow{3}{*}{1.33} & \multirow{3}{*}{10.23} & \multirow{3}{*}{.73} \\
\hline Kitap kapağının rengi & 3.72 & 1.16 & .77 & & & \\
\hline Kitap kapağındaki resim veya şekil & 3.60 & 1.04 & .74 & & & \\
\hline \multicolumn{7}{|l|}{ 5. Faktör: İçindekiler ve Kaynakça } \\
\hline Kitaptaki içindekiler sayfası & 4.11 & 1.03 & .79 & \multirow{2}{*}{1.05} & \multirow{2}{*}{8.10} & \multirow[t]{2}{*}{.63} \\
\hline Kitaptaki kaynakça bölümü & 3.78 & 1.19 & .86 & & & \\
\hline Toplam Açıklanan Varyans & & & & & 70.93 & \\
\hline
\end{tabular}

ORT: Ortalama; S.S.: Standart Sapma; ("5” Çok Önemli,... "1" Hiç Önemli Değil) 
Tablo 2 incelendiği zaman, kitap okumaya etki eden biçimsel değişkenler çerçevesinde beş faktör ortaya çıkmaktadır. Birinci faktör, üç değişkenden oluşmakta olup "cilt ve kâğıt türü" olarak adlandırılmıştır. İkinci faktör, dört değişkenden oluşup "boyut ve yazım özelliği” olarak isimlendirilmiştir. Üçüncü faktör, kitabın içinde kullanılan resim ve şekillerle ilgili olup, "sayfalardaki resim ve şekiller" biçiminde tanımlanmıştır. Faktör analizi sonucunda ortaya çıkan dördüncü faktör, kapakla ilgili resim ve şekilleri kapsayan iki değişkenden oluşup, "kapağın şekli ve rengi" olarak adlandırılmıştır. Son olarak beşinci faktör ise, kitabın içindekiler ve kaynakça kısmı ile ilgili iki değişkeni kapsamakta ve "içindekiler ve kaynakça olarak" isimlendirilmiştir.

Kitap tercihinde etki eden biçimsel faktörlerin belirlenmesinde kullanılan ölçeğin güvenilirliği, Cronbach Alpha katsayısının kullanımı ile ölçülmüştür. Tipik olarak, güvenilirlik katsayılarının 0.70 veya daha yüksek olması, yeterli olarak değerlendirilmektedir (Nunnally, 1978). Ölçekteki toplam on üç değişken için alpha 0.74 olarak hesaplanmıştır.

Ölçeğin güvenilirliği dışında, faktör analizi sonucu ortaya çıkan faktörlerin güvenilirliğini belirlemede güvenilirlik katsayıları kullanılmaktadır. Nunnally (1978) önermiş olduğu 0.70'e ek olarak yeni ölçekler için alpa değerlerinin 0.60 'tan biraz daha yüksek olabileceğini ifade etmektedir. Bu doğrultuda araştırma sonucu ortaya çıkan beş faktörün Alpha güvenilirlik katsayısı birinci faktör için 0.79 , ikinci faktör için 0.67 , üçüncü faktör için 0.81 , dördüncü faktör için 0.73 ve son faktör için ise 0.63 olarak bulunmuştur. Kısacası, beş faktörün üçünün Cronbach Alpha değeri, Nunnally'nin (1978) güvenilirlik için işaret ettiği 0.70 değerinden büyüktür (Kim ve Klenosky, 2003). İki faktör ise 0.63 değerinden büyük olup, yeni geliştirilen ölçekler için Child (1970) tarafından makul olarak gösterilen 0.60 değerinden büyük olması, ölçeğin güvenilirliğin bir işareti olarak değerlendirilebilir. Ayrıca, ölçekte bulunan tüm ifadelerinin güvenilirlik (Cronbach-alpha) değeri 0.74 olup, ölçeğin toplamı önerilen 0.70'in (Nunnally, 1978) üzerinde olması kriteri bakımından da güvenilirliğin yeterli olduğu söylenebilir. 
Faktör analizinde her bir faktörün açıkladığı varyansın yüzdesi faktörlerin göreceli önemini ortaya koymaktadır (Altunışık, Torlak ve Özdemir, 2003). Buna göre, birinci faktör olan "cilt ve kâğıt türü" toplam varyansın en büyük payı olan \%26.78'lik bir kısmını açıklamaktadır. İkinci faktör olan "boyut ve yazım özelliği" toplam varyansın \%13.64'ünü, üçüncü faktör olan "sayfalardaki resim ve şekiller" toplam varyansın \%12.17'sini, dördüncü faktör olan "kapağın şekli ve rengi" toplam varyansın \%10.23'ünü ve son faktör olan "içindekiler ve kaynakça" ise, toplam varyansın \%8.10'unu açıklamaktadır. Tablo 2'de sınıflandırılan beş faktörün toplam varyansın \%70.93'ünü açıkladığı anlaşılmaktadır. Faktör analizi sonucunda ortaya çıkan beş faktörün açıkladığı varyansın yüzde payının yüksek olduğu ifade edilebilir

Açıklanan varyansın yüzdesi bakımından ilk faktör hariç, faktörler arasında önemli bir ayrışmanın olmadığı görülür. İlk faktör olan cilt ve kağıt türü kitabın vereceği ilk izlenim bakımından ön plana çıkmış gibi görünmektedir. Ancak, geriye kalan diğer faktörler biçimsel özelliklerin değerlendirilmesinde azımsanmayacak etkiye sahip olarak görülmektedir. Sonuç olarak faktör analizinde ortaya çıkan bu sonuçların anlamı; kitap okuma ve değerlendirmede biçimsel özelliklerin önemli olduğuna işaret olarak değerlendirilebilir.

Tablo 3: Faktörler Arasındaki Korelasyon Matrisi ve Ortalamalar

\begin{tabular}{|l|l|l|l|l|l|l|c|}
\hline Faktörler & \multicolumn{1}{|c|}{$\mathbf{1}$} & \multicolumn{1}{|c|}{$\mathbf{2}$} & \multicolumn{1}{|c|}{$\mathbf{3}$} & $\mathbf{4}$ & $\mathbf{5}$ & $\begin{array}{l}\text { Art. } \\
\text { Ort. }\end{array}$ & $\begin{array}{c}\text { Std. } \\
\text { Sapma }\end{array}$ \\
\hline $\mathbf{1}$ & 1.00 & & & & & 3.62 & 0.91 \\
$\mathbf{2}$ & $.336^{* *}$ & 1.00 & & & & 3.43 & 0.74 \\
$\mathbf{3}$ & $.153^{* *}$ & $.217^{* *}$ & 1.00 & & & 3.60 & 0.94 \\
$\mathbf{4}$ & $.335^{* *}$ & $.241^{* *}$ & $.278^{* *}$ & 1.00 & & 3.43 & 0.98 \\
$\mathbf{5}$ & .084 & .008 & $.126^{*}$ & -.094 & 1.00 & 3.94 & 0.96 \\
\hline
\end{tabular}

Beş faktörün kendi aralarındaki korelasyon matrisi analiz edildiğinde, birinci faktör ile geriye kalan dört faktörden üç faktör arasında anlamlı bir ilişkinin olduğu $(p<.05$ ve $p<.01)$; aynı şekilde 
ikinci faktör ile geriye kalan üç faktörün ikisi arasında anlamlı ilişki olduğu ( $p<.05$ ve $p<.01$ ); üçüncü faktör ile geriye kalan iki faktör arasında anlamlı bir ilişkinin $(p<.05$ ve $p<.01)$ olduğu bulunmuştur. Tablo 3'teki değerler korelasyon katsayılarını (coefficients of correlation) göstermektedir.

Faktör analizi sonucunda ortaya çıkan beş faktörün aritmetik ortalama (Art.Ort.) ve standart sapmaları (Std.Sapma) analiz edildiğinde; beşinci faktör olan "içindekiler ve kaynakça" 3.947 ortalama ile $(S . S=0.96)$ en yüksek değere sahip iken, ikinci faktör olan "boyut ve yazım özelliği" ise 3.43 ortalama (std. sapma = 0.74 ) ile en düşük değere sahiptir.

\section{Biçimsel Özelliklerle İlgili Tutum Faktörleri}

Kitap okumayı etkileyen biçimsel özelliklere ilişkin 17 tutum ifadesinin ana faktörlere dönüştürülmesi amacıyla Faktör Analizi uygulanmıştır. Yapılan analiz sonuçlarına ilişkin bulgular Tablo 4'de verilmiştir. Üç ifadenin faktör yükleri 0.40'ın altında olması nedeniyle analize dahil edilmemiştir.

Tutum ifadelerine faktör analizinin uygulanması için "örneklem yeterliliğine bakılmış ve yeterliliğe karar vermek için $\mathrm{KMO}$ testinden yararlanılmıştır. Yapılan bu araştırmada KMO 0.824 olup, faktör analizinin uygulanabilmesi için bu oran yeterlidir. Bartlett Test for Sphericity (BTS) $1195.784(p=.000)$ ise bir matris belirleyicisi olarak değişkenlerin varyans hipotezi ve kovaryans matrisinin reddedildiğini ve bir faktör analizi yapmaya uygun olduğunu göstermektedir. Tüm faktörler için öz değer (eigen-value) 1 'den büyük olarak atanmıştır.

Tablo 4 incelendiği zaman, kitap tercihinde etki eden biçimsel değişkenlere ilişkin tutumları ortaya koyan dört faktör ortaya çıkmaktadır. Birinci faktör, altı değişkenden oluşmakta olup "dikkat ve izlenim" olarak adlandırılmıştır. İkinci faktör, üç değişkenlidir ve "isteklilik" olarak isimlendirilmiştir. Üçüncü faktör, biçimsel özelliklerin okuma zevki ile ilgili olup, bu bakımdan "okuma zevki" biçiminde tanımlanmıştır. 
Tablo 4: Biçimsel Özelliklere Ilişkin Tutum Faktörleri

\begin{tabular}{|c|c|c|c|c|c|c|}
\hline Faktörler & ORT. & S.S. & $\begin{array}{l}\text { Faktör } \\
\text { Yükleri }\end{array}$ & $\begin{array}{c}\text { Öz } \\
\text { Değer }\end{array}$ & $\begin{array}{c}\text { Açıklanan } \\
\text { Varyansın } \\
\text { \%'si }\end{array}$ & $\begin{array}{c}\text { Alpha } \\
\qquad a\end{array}$ \\
\hline $\begin{array}{l}\text { 1.Faktör: Dikkat ve İzlenim } \\
\text { Kitabı elime aldığımda biçimsel ilk izlenim } \\
\text { kitabı okumamı etkiler } \\
\text { Biçimsel olarak oluşturulmuş kitaplar } \\
\text { dikkatimi çeker } \\
\text { Biçimsel özellikler algılamamı etkiler } \\
\text { Biçimsel özellikler okumamı kolaylaştıır } \\
\text { İçerik kadar biçimsel özellikler de önemlidir } \\
\text { Biçimsel özellikler okuma hızımı etkiler }\end{array}$ & $\begin{array}{l}3.93 \\
\\
4.03 \\
3.89 \\
3.66 \\
3.68 \\
3.55\end{array}$ & $\begin{array}{l}0.98 \\
\\
0.89 \\
0.90 \\
0.95 \\
0.93 \\
1.09\end{array}$ & $\begin{array}{l}.71 \\
.64 \\
.82 \\
.77 \\
.59\end{array}$ & 4.35 & 31.05 & .83 \\
\hline $\begin{array}{l}\text { 2. Faktör: İsteklilik } \\
\text { Kitabın sıkıcı olup olmaması biçimsel } \\
\text { özelliklerle ilgilidir } \\
\text { Sayfa sayısı algılamamı etkiler } \\
\text { İçerik olarak iyi ancak biçimsel özellikleri } \\
\text { kötü olan kitapları okumaktan } \\
\text { vazgeçebilirim }\end{array}$ & $\begin{array}{l}2.57 \\
2.93 \\
\\
2.44\end{array}$ & $\begin{array}{l}1.19 \\
1.19 \\
\\
1.14\end{array}$ & $\begin{array}{l}.69 \\
.64 \\
.74\end{array}$ & 1.67 & 11.92 & .63 \\
\hline $\begin{array}{l}\text { 3. Faktör: Okuma Zevki } \\
\text { Kitapta resim ve şekil kullanımı, okumada } \\
\text { zevk almamı etkiler } \\
\text { Kitapta kullanılan punto ve şekil aralığı, } \\
\text { okuma zevkimi etkiler } \\
\text { Kitapta kullanılan sayfa sayısı ve cilt türü } \\
\text { gibi Özellikler okuma zevkimi etkiler }\end{array}$ & $\begin{array}{l}3.84 \\
3.40\end{array}$ & $\begin{array}{l}0.96 \\
1.00 \\
1.06\end{array}$ & $\begin{array}{l}.70 \\
.66 \\
.54\end{array}$ & 1.16 & 8.29 & .50 \\
\hline $\begin{array}{l}\text { 4. Faktör: Kolaylaştııcılık } \\
\text { Kitabın sonundaki sözlük, kitabın içindeki } \\
\text { konuları daha iyi anlamamı sağlar } \\
\text { Kitabın sonundaki alfabetik konu dizini, } \\
\text { kitabı daha iyi kullanmamı sağlar }\end{array}$ & 4.10 & 0.84 & .77 & 1.09 & 7.77 & .68 \\
\hline Toplam Açıklanan Varyans & & & & & 59.03 & \\
\hline
\end{tabular}

ORT: Ortalama; S.S.: Standart Sapma; ("5" Tamamen Katılıyorum "1" Hiç Katılmıyorum)

Biçimsel özelliklere ilişkin tutumları ortaya koyan dördüncü ve son faktör, okumayı kolaylaştırıcı işlevi kapsamakta olup, "kolaylaştırıcılık" olarak adlandırılmıştır. Her bir faktöre ilişkin 
güvenilirlik katsayısı (Cronbach-alpha $=\alpha$ ) 0.83 ile 0.50 arasında değişmektedir. 14 ifadeden oluşan ölçeğin güvenilirliği 0.79 olup; birinci faktörün güvenilirliği 0.83 'tür. Dördüncü faktör 0.68 olup önerilen değer olan 0.70 'e oldukça yakındır. İkinci faktör ise 0.63 olup yeni bir ölçek olarak öngörülen 0.60 'ın üzerindedir. Zira, 0.63 değeri yeni geliştirilen ölçekler için Child (1970) tarafından makul olarak gösterilen 0.60 değerinden büyük olması, ölçeğin güvenilirliğin bir işareti olarak değerlendirilebilir. Üçüncü faktörün alpha değeri ise 0.50 olup bu değer düşük olarak değerlendirilebilir. Ancak ölçeğin toplam güvenilirlik değerinin 0.79 olması bu değerin makul olarak kabul edilmesi şeklinde değerlendirilebilir.

Faktör analizinde her bir faktörün açıkladığı varyans değerlendirildiğinde, birinci faktör olan "dikkat ve izlenim" toplam varyansın en büyük payı olan \%31.05'lik bir kısmını açıklamaktadır. İkinci faktör olan "isteklilik" toplam varyansın \%11.92'sini, üçüncü faktör olan "okuma zevki" toplam varyansın \%8.29'unu, dördüncü ve son faktör olan "kolaylaştırıcılık" toplam varyansın \%7.77'sini açıklamaktadır. Kitap tercihinde etkili olan biçimsel özelliklere ilişkin tutumların sınıflandırılmasında ortaya çıkan dört faktör, toplam varyansın \%59.03'ünü açıkladığı ve açıklanan varyansın yüzde payının yüksek olduğu ifade edilebilir.

Tablo 5: Faktörler Arasındaki Korelasyon Matrisi ve Ortalamalar

\begin{tabular}{|l|l|l|l|l|l|l|}
\hline Faktörler & \multicolumn{1}{|c|}{$\mathbf{1}$} & $\mathbf{2}$ & $\mathbf{3}$ & $\mathbf{4}$ & $\begin{array}{c}\text { Art. } \\
\text { Ort. }\end{array}$ & S.S. \\
\hline $\mathbf{1}$ & 1.00 & & & & 3.79 & 0.70 \\
$\mathbf{2}$ & $.457^{* *}$ & 1.00 & & & 2.65 & 0.90 \\
$\mathbf{3}$ & $.412^{* *}$ & $.270^{* *}$ & 1.00 & & 3.73 & 0.71 \\
$\mathbf{4}$ & .046 & $-.126^{*}$ & .049 & 1.00 & 4.01 & 0.79 \\
\hline
\end{tabular}

${ }^{*} p<.05 ;{ }^{* *} p<.01 ; " 5$ " Tamamen Katılıyorum, ..."1" Hiç Katılmıyorum

Tutumları ortaya koyan dört faktörün kendi aralarındaki korelasyon matrisi analiz edildiğinde, birinci faktör ile ikinci ve üçüncü faktör arasında anlamlı bir ilişkinin olduğu $(p<.05$ ve $p<$ .01 ); ikinci faktör ile geriye kalan iki faktör arasında anlamlı ilişki 
olduğu $(p<.05$ ve $p<.01)$; üçüncü faktör ile geriye kalan faktör arasında ise anlamlı bir ilişkinin ( $p>.05$ ) olmadığı bulunmuştur. Faktör analizi sonucunda ortaya çıkan dört faktörün aritmetik otalama (Art.Ort.) ve standart sapmaları (S.S.) analiz edildiğinde; dördüncü faktör olan "kolaylaştırıcılık" 4.01 ortalama ile (S.S.=0.79) en yüksek değere sahip iken, ikinci faktör olan "isteklilik" ise 2.65 ortalama $(S . S=0.90)$ ile en düşük değere sahiptir (Bkz. Tablo 5).

\section{Biçimsel Özelliklerin Tutum Faktörleri Üzerindeki Etkisi}

Kitap okumayı etkileyen biçimsel özellikler ile okuma niyetini ortaya koyan dikkat ve izlenim, isteklilik, okuma zevki ve kolaylaştırıcılık arasındaki ilişkileri belirlemek amacıyla çoklu regresyon analizinden yararlanılmıştır.

Tablo 6: Biçimsel Özelliklerin Okuma İşlevi Üzerine Etkisi

\begin{tabular}{|c|c|c|c|c|c|c|}
\hline \multirow{4}{*}{ Faktörler } & \multicolumn{6}{|c|}{ Bağımlı Değişken } \\
\hline & \multicolumn{6}{|c|}{ Dikkat ve İzlenim } \\
\hline & \multirow[b]{2}{*}{ Std. $\beta$} & \multirow[b]{2}{*}{$\mathbf{t}$} & \multirow[b]{2}{*}{$\mathbf{p}$} & \multirow[b]{2}{*}{$\mathbf{R}^{2}$} & \multirow{2}{*}{$\begin{array}{c}\text { Ayar. } \\
\mathbf{R}^{2}\end{array}$} & \multirow[b]{2}{*}{$\mathbf{F}$} \\
\hline & & & & & & \\
\hline Cilt ve Kâğıt Türü & 0,329 & 6,577 & $0.000^{* *}$ & \multirow{6}{*}{0.27} & \multirow{6}{*}{0.26} & \multirow{6}{*}{$21.591^{* *}$} \\
\hline Boyut ve Yazım Özelliği & 0,103 & 2,068 & $0.040^{*}$ & & & \\
\hline Sayfalardaki Resim ve Şekiller & 0,106 & 2,115 & $0.035^{*}$ & & & \\
\hline Kapağın Şekli ve Rengi & 0,370 & 7,390 & $0.000^{* *}$ & & & \\
\hline İçindekiler ve Kaynakça & $-0,061$ & $-1,222$ & 0.223 & & & \\
\hline Sabit & & 113.011 & $0.000^{* *}$ & & & \\
\hline${ }^{*} p<0.05 ;{ }^{* *} p<0.01$ & & & & & & \\
\hline
\end{tabular}

Tablo 6'da görüldüğü gibi sonuçlar, regresyon modelinin istatistiksel olarak anlamlı olduğunu göstermiş olup $(F=21.591 ; p$ $<0.01$ ), kitap okumayı etkileyen biçimsel faktörlerin dikkat ve izlenim adlı bağımlı değişkenin tamamının \%26'sını açıklamaktadır. Regresyona ilişkin standardize edilmiş beta $(\beta)$ değerleri bakımından incelendiğinde kapağın şekli ve rengi $(\beta=$ 
0.370; $p<0.01)$ ile cilt ve kağıt türünün $(\beta=0.329 ; p<0.01)$ dikkat ve izlenim değişkeninin tamamı üzerinde en güçlü etkiye sahip olduğu görülmektedir. Bu faktörleri ise sayfalardaki resim ve şekiller ile boyut ve yazım özelliği takip etmektedir. Son faktör olan içindekiler ve kaynakça ise anlamlı bir etkiye sahip değildir. Sonuç olarak, okuma işlevi ile kitap okumayı etkileyen biçimsel özellikler arasında istatistiksel olarak anlamlı bir ilişki bulunmaktadır.

Tablo 7: Biçimsel Özelliklerin Okuma İstekliliği Üzerine Etkisi

\begin{tabular}{|c|c|c|c|c|c|c|}
\hline \multirow[b]{3}{*}{ Faktörler } & \multicolumn{6}{|c|}{ Bağımlı Değişken } \\
\hline & \multicolumn{6}{|c|}{ İsteklilik } \\
\hline & Std. $\beta$ & $\mathbf{t}$ & $\mathbf{p}$ & $\mathbf{R}^{2}$ & $\begin{array}{l}\text { Ayar. } \\
\mathbf{R}^{2}\end{array}$ & $\mathbf{F}$ \\
\hline $\begin{array}{l}\text { Cilt ve Kâğıt Türü } \\
\text { Boyut ve Yazım Özelliği } \\
\text { Sayfalardaki Resim ve Şekiller } \\
\text { Kapağın Şekli ve Rengi } \\
\text { İçindekiler ve Kaynakça } \\
\text { Sabit }\end{array}$ & $\begin{array}{l}0.172 \\
0.172 \\
-0.073 \\
0.274 \\
-0.195\end{array}$ & $\begin{array}{l}3.248 \\
3.238 \\
-1.384 \\
5.161 \\
-3.682 \\
54.973\end{array}$ & $\begin{array}{l}0.001^{* *} \\
0.001^{* *} \\
0.167 \\
0.000^{* *} \\
0.000^{* *} \\
0.000^{* *}\end{array}$ & 0.18 & 0.16 & $12.622^{* \star}$ \\
\hline${ }^{*} p<0.05 ;{ }^{* *} p<0.01$ & & & & & & \\
\hline
\end{tabular}

Tablo 7, kitapların biçimsel özelliklerinin kitap okuma istekliliği üzerindeki etkisini ortaya koymak amacıyla yapılan regresyon sonuçlarını göstermektedir. Tabloda görüldüğü gibi, regresyon modeli sonuçları, ortaya konan regresyon modelinin istatistiksel olarak anlamlı olduğunu göstermiş olup ( $F=12.622$; $p<0.01)$, kitap okumayı etkileyen biçimsel faktörlerin okuma istekliği adlı bağımlı değişkenin tamamının \%16'sını açıklamaktadır. Regresyona ilişkin standardize edilmiş beta $(\beta)$ değerleri bakımından incelendiğinde kapağın şekli ve rengi $(\beta=0.274 ; p<0.01)$, cilt ve kağıt türü $(\beta=0.172 ; p<0.01)$ ile boyut ve yazım özelliği $(\beta=0.172 ; p<0.01)$ okuma istekliliği değişkeninin tamamı üzerinde en güçlü etkiye sahip olduğunu göstermektedir. Bu faktörleri içindekiler ve kaynakça özelliği takip etmektedir. Sayfalardaki resim ve şekiller ise okuma 
istekliliği üzerinde anlamlı bir etkiye sahip değildir. Kısaca, kitap okumayı etkileyen biçimsel özellikler ile kitap okuma istekliliği arasında istatistiksel olarak anlamlı bir ilişki bulunmaktadır.

Tablo 8: Biçimsel Özelliklerin Okuma Zevki Üzerine Etkisi

\begin{tabular}{|c|c|c|c|c|c|c|}
\hline \multirow{4}{*}{ Faktörler } & \multicolumn{6}{|c|}{ Bağımlı Değişken } \\
\hline & \multicolumn{6}{|c|}{ Okuma Zevki } \\
\hline & \multirow[b]{2}{*}{ Std. $\beta$} & \multirow[b]{2}{*}{$\mathbf{t}$} & \multirow[b]{2}{*}{$\mathbf{P}$} & \multirow[b]{2}{*}{$\mathbf{R}^{2}$} & \multirow{2}{*}{$\begin{array}{c}\text { Ayar. } \\
\mathbf{R}^{2}\end{array}$} & \multirow[b]{2}{*}{$\mathbf{F}$} \\
\hline & & & & & & \\
\hline Cilt ve Kâğıt Türü & 0.316 & 6.247 & $0.000^{* *}$ & \multirow{6}{*}{0.25} & \multirow{6}{*}{0.24} & \multirow{6}{*}{$19.924^{* *}$} \\
\hline Boyut ve Yazım Özelliği & 0.265 & 5.235 & $0.000^{* *}$ & & & \\
\hline Sayfalardaki Resim ve Şekiller & 0.280 & 5.532 & $0.000^{* *}$ & & & \\
\hline Kapağın Şekli ve Rengi & 0.075 & 1.478 & 0.141 & & & \\
\hline İçindekiler ve Kaynakça & \multirow[t]{2}{*}{0.025} & \multirow{2}{*}{$\begin{array}{c}0.487 \\
106.617\end{array}$} & 0.627 & & & \\
\hline Sabit & & & $0.000^{* *}$ & & & \\
\hline${ }^{*} p<0.05 ;{ }^{* *} p<0.01$ & & & & & & \\
\hline
\end{tabular}

Tablo 8, kitapların biçimsel özelliklerinin okuma zevki üzerindeki etkisini ortaya koymak amacıyla yapılan regresyon sonuçlarını göstermektedir. Tablodan görüldüğü gibi, regresyon modeli sonuçları, ortaya konan regresyon modelinin istatistiksel olarak anlamlı olduğunu göstermiş olup $(F=19.924 ; p<0.01)$, kitap okumayı etkileyen biçimsel faktörlerin okuma zevki adlı bağımlı değişkenin tamamının \%24'ünü açıklamaktadır. Regresyona ilişkin standardize edilmiş beta $(\beta)$ değerleri bakımından incelendiğinde cilt ve kağıt türü $(\beta=0.316 ; \quad p<0.01)$ okuma zevki değişkeni üzerinde en güçlü etkiye sahiptir. Sayfalardaki resim ve şekiller $(\beta=0.280 ; p<0.01)$ ile boyut ve yazım özelliği $(\beta=0.265 ; p<0.01)$ ikinci sırada güçlü bir etkiye sahiptir. Kapağın şekli ve rengi ile içindekiler ve kaynakça özellikleri okuma zevki üzerinde anlamlı bir etkiye sahip değildir. 
Tablo 9: Biçimsel Özelliklerin Kolaylaştırıcılık Üzerine Etkisi

\begin{tabular}{|c|c|c|c|c|c|c|}
\hline \multirow{4}{*}{ Faktörler } & \multicolumn{6}{|c|}{ Bağımlı Değişken } \\
\hline & \multicolumn{6}{|c|}{ Kolaylaştırıcılık } \\
\hline & \multicolumn{6}{|c|}{ Ayar. } \\
\hline & Std. $\beta$ & $\mathbf{t}$ & $\mathbf{p}$ & $\mathbf{R}^{2}$ & $\mathbf{R}^{2}$ & $\mathbf{F}$ \\
\hline Cilt ve Kâğıt Türü & -0.074 & -1.418 & 0.157 & & & \\
\hline Boyut ve Yazım Özelliği & -0.067 & -1.279 & 0.202 & & & \\
\hline Sayfalardaki Resim ve Şekiller & 0.257 & 4.938 & $0.000^{\star *}$ & $02 ?$ & 020 & $15799^{* *}$ \\
\hline Kapağın Şekli ve Rengi & -0.033 & -639 & 0.523 & 0.22 & 0.20 & \\
\hline İçindekiler ve Kaynakça & 0.371 & 7.110 & $0.000^{* *}$ & & & \\
\hline Sabit & & 93.409 & $0.000^{\star *}$ & & & \\
\hline${ }^{*} p<0.05 ;{ }^{* *} p<0.01$ & & & & & & \\
\hline
\end{tabular}

Kitapların biçimsel özelliklerinin kolaylaştırıcılık üzerindeki etkisini ortaya koymak amacıyla yapılan regresyon sonuçları Tablo 9'da gösterilmektedir. Regresyon modeli sonuçları, ortaya konan regresyon modelinin istatistiksel olarak anlamlı olduğunu göstermiş olup ( $F=15.799 ; p<0.01)$, kitap okumayı etkileyen biçimsel faktörlerin kolaylaştırıcılık adlı bağımlı değişkeninin tamamının \%20'sini açıklamaktadır. Regresyona ilişkin standardize edilmiş beta $(\beta)$ değerleri bakımından incelendiğinde içindekiler ve kaynakça $(\beta=0.371 ; p<0.01)$ ile sayfalardaki resim ve şekiller $(\beta=0.257$; $p<0.01)$ kolaylaştırıcılık üzerinde güçlü bir etkiye sahiptir. Geriye kalan biçimsel özellikler kolaylaştıııcılık üzerinde anlamlı bir etkiye sahip değildir.

\section{Tartışma ve Sonuç}

Kitapların tercihinde etkili olan birçok nitelik içinde biçimsel özellikler de bulunmaktadır. Kitapların biçimsel özellikleri öncelikle kitapların tercih edilmesini, sonrasında ise okuyucunun kitabı okumasını büyük bir oranda etkilemektedir. Bu açıdan yayınevleri ve kitap tasarımıyla uğraşan kişilerin, okuyucuları dikkate alarak, onların beklentileri doğrultusunda ürünü (kitap) sunmaları gerekmektedir. Bu açıdan okuyucuyu temel alan bir yaklaşımla ürünün pazara sunulması gerekmektedir. 
Kitap tüketicilerine en uygun ürünlerin sunumu için, okuyucu bakış açısını ortaya koyan modern yaklaşımlar büyük önem taşır. $\mathrm{Bu}$ çerçeveden hareketle gerçekleştirilen çalışmada, tüketici gözüyle kitap okuyucularının kitapların biçimsel özelliklerini ortaya koyan beş önemli faktör ortaya çıkmıştır. Bunlar sırası ile; cilt ve kağıt türü, boyut ve yazım özelliği, sayfalardaki resim ve şekiller, kapağın rengi ve şekli ile içindekiler ve kaynakçadır. İlk faktör olan cilt ve kağıt türü, açıklanan varyansın en büyük kısmını açıklamaktadır. Tüm faktörler değerlendirmeye alındığında ise toplam açıklanan varyans $\% 70.93$ olup, bu oranın sosyal bilimlerde yapılan araştırmalar için kabul sınırının üstünde olduğu ifade edilebilir. Faktör ortalamaları değerlendirildiğinde 3.947 ortalama ile içindekiler ve kaynakça ilk sırada yer alırken, bunu 3.626 ortalama ile cilt ve kâğıt türü takip etmektedir.

İkinci olarak kitapların biçimsel özelliklerinin kitap okuma işlevi üzerinde etkili olan dört tutum faktörü ortaya çıkmıştır. Bunlar sırası ile; dikkat ve izlenim, isteklilik, okuma zevki ve kolaylaştırıcılıktır. İlk faktör olan dikkat ve izlenim açıklanan varyansın büyük kısmını açıklamaktadır. Tüm faktörler değerlendirmeye alındığında ise toplam açıklanan varyans \%59.03'tür. Faktör ortalamaları değerlendirildiğinde, kolaylaştırıcılık 4.01 ortalama ile ilk sırada, dikkat ve izlenim 3.79 ortalama ile ikinci sırada yer almaktadır.

Kitapların biçimsel özelliklerinin okuma işlevine yönelik tutum faktörleri üzerindeki etkilerini ortaya koymak için yapılan regresyon analizi sonucunda; biçimsel özelliklerin dikkat ve izlenim olarak isimlendirilen faktörün tamamının \%26'sını, isteklilik faktörünün \%16'sını, okuma zevki faktörünün tamamının \%24'ünü ve kolaylaştırıcılık faktörünün tamamının \%20'sini etkilediği bulunmuştur.

$\mathrm{Bu}$ araştırmada elde edilen bulgular doğrultusunda, kitap tasarımlarında biçimsel özelliklere dikkat edilmesi gerektiğini söylemek mümkündür. Çoğu durumda kitapların biçimsel özellikleri sadece kitabın fark edilip, tercih edilmesinde değil sonraki aşamada da büyük bir öneme sahip olduğu söylenebilir. Çünkü kitabın biçimsel özellikleri kitap okuyucularının dikkat/izlenim, kitap 
okuma istekliliği, okuma zevki ve okumayı kolaylaştırma gibi konular üzerinde büyük bir etkiye sahiptir. Örneğin kitapta resim ve şekil kullanımı, punto, sayfa yapısı, cilt türü gibi biçimsel özellikler okuyucunun okuma zevkini etkilemektedir. Bununla birlikte kitabın sonunda sözlük veya alfabetik konu dizini, kitabın okunmasını kolaylaştıracak biçimsel özellikler içerisinde sayılabilir.

Ürün bağlamında yapılan değerlendirmelerde, kitapların biçimsel özellikleri okuyucu üzerinde bir etki yaratabilmektedir. Bu nedenle, kitap basımı yapan yayın evlerinin kitapları okuyucu intiyaçlarını temel alarak tasarlaması ve uygun biçimde tasarlaması ve basması daha yararlı sonuçlar verebilecektir.

\section{Sınırlılıklar ve Gelecek Araştırmalar}

Gerçekleştirilen bu çalışma, Anadolu Üniversitesi Yunus Emre Kampüsü'ndeki Merkez Kütüphane'den yararlanan öğrencileri kapsamaktadır. Araştırmaya kitap okumayı etkileyen kitap türü, yazar, anlatım biçimi gibi özelliklerin ayrımına gidilmeksizin, genel olarak kitap okumayı etkileyen biçimsel özellikler ve biçimsel özelliklere yönelik tutum faktörleri ile sınırlı tutulmuştur. Bu bakımdan, elde edilen bulgular ve sonuçlar değerlendirildiğinde sadece bu unsurlar dikkate alınmıştır. Araştırmada rapor edilen bulgular küçük ölçekli bir örneklem grubu üzerinde yapılmış olması diğer bir kısıtııı̆ı ortaya koymaktadır.

Gelecekte bu alanda yapılacak araştırmalarda, daha fazla sayıda kütüphane okuyucusunu kapsayan çalışmaların gerçekleştirilmesi, daha net biçimde genellenebilir sonuçlar verebilir. Bunun yanı sıra, biçimsel özelliklere ek olarak kitap okumayı etkileyen diğer özelliklerin (yazar, tür, içerik ve yayınevi) dikkate alındığı geniş kapsamlı çalışmalar, daha anlamlı sonuçlar sağlayabilir. Aynı zamanda bu tür çalışmalar, eğitim düzeyine göre farklılaşabilir. Gelecekte farklı eğitim düzeyindeki kişilerle yapılacak çalışmalar, yayınevlerinin hedef kitle olarak belirlediği gruplara yönelik olarak daha ayrıntılı ipuçları verebilir. 


\section{Kaynakça}

2006 yılında Türkiye'de 35 bin kitap basıldı. (2007, 16 Ocak). 26 Kasım 2007 tarihinde http://kitabihayat.wordpress.com/2007 /01/16/2006-yilinda-turkiyede-35-bin-kitap-basildi/ adresinden erişildi.

Akınoğlu, O., Şahin, F. ve Gürdal, A. (2008). Fen bilgisi ders kitaplarının kavram haritası çizilerek değerlendirilmesi. 27 Şubat 2008 tarihinde http://www.fedu.metu.edu.tr/ufbmek5/b_kitabi/PDF/Fen/Bildiri/t54d.pdf adresinden erişildi.

Altunışık, R, Torlak, Ö ve Özdemir, Ş. (2003). Ekonomik kriz ve değişen alışveriş alışkanlıkları üzerine bir araştırma. 8. Ulusal Pazarlama Kongresi Bildiriler Kitabı, 16-19 Ekim 2003 içinde (ss. 327-343). Kayseri: Erciyes Üniversitesi.

Altunışık, R., Çoşkun, R., Bayraktaroğlu, S. ve Yıldııım, E. (2005). Sosyal bilimlerde araştırma yöntemleri: SPSS uygulamalı (4.bs.). Adapazarı: Sakarya Kitabevi.

Ayyıldız, M., Bozkurt, Ü. ve Canlı, S. (2006). Okuma kültürü üzerine bir araştırma. 28 Kasım 2007 tarihinde http://yayim.meb.gov.tr/dergiler/169/mustafa.doc adresinden erişildi.

Babin, L. A., Babin, B. J. ve Boles, J. S. (1999). The effects of consumer perceptions of the salesperson, product and dealer on purchase intentions. Journal of Retailing and Consumer Services, 6, 91-97.

Blake, V.L.P. (1989). The role of reviews and reviewing media in the selection process: An examination of the research record. Collection Management, 11, 39.

Bowker News Release. (2004). U.S. book production soars to 175,000 new titles in 2003. 3 Ocak 2005 tarihinde http://www.bowker.com/press/2004_0527_bowker.htm adresinden erişildi.

Child, D. (1970). The essentials of factor analysis. London: Holt, Rhinehart and Winston. 
D'Astous, A., Colbert, F. ve Mbarek, I. (2006). Factors influencing readers' interest in new book releases: An experimental study. Poetics, 34, 134-147.

Edelman, H. ve Muller, K. (1987). A new look at the library market. Publishers Weekly, 23 (May 28): 32.

Erdoğan, İ. (1998). Araştırma dizaynı ve istatistik yöntemleri. Ankara: Emel Matbaası.

Futas, E. (1977). Library acquisition policies and procedures. Phoenix: Oryx Press.

İftar,G. K. (2000). Bilimsel araştırma yöntemleri. 18 Eylül 2006 tarihinde http://bde.anadolu.edu.tr/ (http://193.140.21.192 :8000/SCRIPT/bay2/scripts/student/serv_page.pl?970127244 +bay0401.html) adresinden erişildi.

İslamoğlu, A. H. (2006). Pazarlama yönetimi. İstanbul: Beta Yayınları.

Kamphuis, J. (1991). Satisfaction with books: Some empirical findings. Poetics, 20, 471-485.

Kim, S. S., Lee, C. K. ve Klenosky, D. B. (2003). The influence push and pull factors at Korean national parks. Tourism Management, 24, 169-180.

Kurulgan, M. ve Argan, M. (2006). Yeni kitap seçiminde etkili olan biçimsel faktörlerin okuyucu perspektifinden değerlendirilmesi. Bilgi Dünyası, 7(2): 230-249.

Kurtuluş, K. (1998). Pazarlama araştırmaları. Genişl. 6. Baskı. İstanbul: İstanbul Üniversitesi İşletme Fakültesi Yay. No: 274.

Leemans, H. (1988). Who buys literary books? Cultural Economics, 88, 123-130.

Leemans, H.ve Stokmans, M. (1992). A descriptive model of the decision making process of buyers of books. Journal of Cultural Economics, 16, 25-50. 
Lin, T. M. Y., Luarn, P. ve Huang, Y. K. (2005). Effect of internet book reviews on purchase intention: a focus group study. The Journal of Academic Librarianship, 31(5): 461-468.

McDonald, C. (1991). Sponsorship and the image of the sponsor. European Journal of Marketing 25, 31-38.

Meenaghan, T.(1983). Commercial sponsorship. European Journal of Marketing 17,5-73.

Nakip, M. (2004). Pazarlama araştırmalarına giriş (SPSS destekli). Ankara: Seçkin Yayıncılık.

Noyes, J., ve Garland, K. (2005). Students' attitudes toward books and computers. Computers in Human Behavior. 21(2): 233-241.

Nunnally, J. C. (1978). Psychometric theory (2nd ed.). New York: McGraw-Hall.

Odabaşı, Y. ve Barış, G. (2002). Tüketici davranışı (4.bs.). MediaCat Yay., İstanbul.

Piters, R. ve Stokmans, M. (1997). The influence of typicality of book covers on preferences. G. Guzman, A. Jose ve S. Sanz (Ed.), The 22nd International Colloquium of Economic Psychology. 1, 37-50.

Richins, M. L. ve Bloch, P. H. (1991). Post-purchase product satisfaction: incorporating the effects of involvement and time. Journal of Business Research, 23, 145-158.

Schiffman, L. G. ve Kanuk, L. L. (2000). Consumer behavior (7th ed.). New Jersey: Prentice Hall.

Sever, S. (2007, Ağustos). Çocuk kitaplarında bulunması gereken yapısal ve eğitsel özellikler. 27 Kasım 2007 tarihinde http://www.egitim.aku.edu.tr/ssever.htm adresinden erişildi.

Stokes, R. C. (1985). The effect of price, package design, and brand familiarity on perceived quality. Lexington, MA: Lexington Books. 
Stokmans, M. ve Hendrickx, M. (1994). The attention paid to new book releases on a display table. Poetics, 22, 185-197.

Tortop, R. ve Barışcan, H. (2007, 12 Temmuz), Türkçe 1. sınıf ders kitabı özellikleri. 27 Kasım 2007 tarihinde http://www.odevsel.com/egitim/2335/turkce-1-sinif-ders-kitabiozellikleri.html adresinden erişildi.

Uçak (Özenç) N. ve Güzeldere (Olşen), Ş. (2006). Bilişsel yapının ve işlemlerin bilgi arama davranışı üzerine etkisi. Türk Kütüphaneciliği, 20, 7-28.

Wang, P. ve Soergel, D. (1998). A cognitive model of document use during a research project: Study 1. Document selection. Journal of the American Society for Information Science, 49(2), 115-133.

Yükselen, C. (2000). Pazarlama araştırmaları. Ankara: Detay Yayıncılık.

Zhang, J. J., Pennington-Gray, L., Connaughton, D. P., Braunstein, J. R., Ellis, M. H., Lam, E. T. C. ve diğerleri. (2003). Understanding women's professional football game spectators: sociodemographics, game consumption, and entertainment options. Sport Marketing Quarterly, 12(4): 228-243. 